\title{
Editor's Note: Choreography, Aesthetics, and State Violence
}

It is rare that a nonthemed issue of $D R J$ should contain a sustained reflection on one theme broadly conceived: the role played by choreography and gestural sequences in state violence; the consensus necessary to the maintenance of violent regimes as lodged within corporeal aesthetics; and, above all, the heritage of this violence-what has allowed it to germinate and take hold within cultural practice as gestural sequence. Ranging across the twentieth and into the twenty-first century from Germany to Argentina to Israel, these articles also offer in their ensemble something approaching a historical theory of that relation. In addition, with two articles on Germany and two on Argentina the unusual possibility of comparison arises, which is rare in scholarly journals. At the same time, contemporary Israel provides another interesting point of comparison with the earlier two sites.

While the discussion of how early modern dance drew on physical culture movements in Europe and the United States is not new, Marion Kant's treatment of it in "German Gymnastics, Modern German Dance, and Nazi Aesthetics" is. This is because Kant brings the question of a Nazi aesthetic - a premise that reaches beyond the specter of accommodation-to the forefront of her analysis. Rather than focus on cultural production of the early twentieth century, she returns to the nineteenth century-historical dance studies' new frontier. Kant plumbs the origins of the gymnastics movement in the work of Friedrich Ludwig Jahn, who innovated in and successfully established the bond between gymnastics and racial identity that was also a requirement for national belonging. While Kant's case ultimately comes to rest with Rudolf Laban's movement choirs, the sense of a Nazi movement aesthetic is derived from a social movement in which physical practices that obtain definition as aesthetic also undergirded Nazi ideology.

Alexandra Kolb’s “Wigman's Witches: Reformism, Orientalism, Nazism” takes as it focus three versions of Mary Wigman's Witch Dance (Hexentanz). Exploring in depth the differences between these three versions of an iconic dance, Kolb is able to unfold the ideological implications of each version with respect to ideologies that ultimately converge in Nazism by the early 1930s. Thus, although distinct from Kant's methodology as concerns her object of study-a particular work-Kolb's treatment is actually quite consonant with a different and innovative approach to this subject matter.

Turning to Argentina, Victoria Fortuna's "Dancing Argentine Modernity: Imagined Indigenous Bodies on the Buenos Aires Concert Stage (1915-1966)" compares and contrasts two moments of Argentine dance modernity. With the visits of the Ballets Russes to Argentina in the early twentieth century a project was conceived for a ballet that Nijinsky would choreograph in which pre-Columbian indigenous myths would serve as springboard for a new Rite of Spring. Fortuna brings that failed project into relation with Oscar Araiz's La consagración de la primavera (1966) to show how that work may have fulfilled the promise of Argentine choreographic modernity at the expense of indigenism. 
Juan Ignacio Vallejos in his "Dance, Sexuality, and Utopian Subversion Under the Argentine Dictatorship of the 1960s: The Case of Oscar Aráiz's The Rite of Spring and Ana Itelman's Phaedra" again puts the work of Aráiz front and center. However, Vallejos sees it as not only as a contribution to Argentine dance modernism, but as a political contestation during the repressive regime of Onganía's dictatorship. Hence, Vallejos reads Aráiz's work as an example of subversive utopia with a focus on sexual self-determination. Placing the work thus within the context of 1960s youth culture and censorship, Vallejos draws very different conclusions about dance modernity in Argentina. Here I would just note that an important choreographic work about which relatively little has been known outside of Argentina until now is presented in this issue from quite diverse perspectives, engendering a fascinating dialogue.

Frédéric Pouillaude's "Dance as Documentary: Conflictual Images in the Choreographic Mirror (On Archive by Arkadi Zaides)" deals with a contemporary work currently being performed by an Israeli choreographer. Here the subject is violence sanctioned by the state. Pouillaude begins with the striking insight that conceptual dance of the self-reflexive variety is evolving toward documentary dance in which the reflexivity is redirected toward the external world. Through another wonderful insight, that of the gestuitum ("the analytic productivity of choreographic composition"), Pouillaude manages to explain how the becoming autonomous of learned gesture as performed accomplishes an analysis whose power resides in the collectivity of that gesture. In this sense, we have exactly the reverse operation of ideology as outlined in the earlier essays but a parallel focus on choreographic aesthetics. And, also in this sense, the relation of dance to state violence is given a historical dimension, something like historical "progress." With Pouillaude, it is gestural sequence that becomes isolated, subtracted, as it were, from a chaotic continuum of actions, and displayed as "analysis" of violence-a striking reversal.

Mark Franko Editor, $D R J$ 